\title{
An edifying circle of pastors
}

\begin{abstract}
Book Title:
The Genevan School of the Prophets. The congrégations of the Company of Pastors and their Influence in the 16th Century Europe (Travaux d'Humanisme et Renaissance, No DXII)
\end{abstract}



Author: Erik de Boer

ISBN:

978-2-600-01611-7

Publisher:

Librairie Droz, Genève, 2012 pp. 330, ZAR760.00*

*Book price at time of review

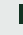

Review Title:

An edifying circle of pastors

Reviewer:

H.H. van Alten ${ }^{1}$

\section{Affiliation:}

${ }^{1} J o n a t h a n$ Edwards Centre Africa, University of the Free State, South Africa

Email:

hhvanalten@gmail.com

Postal address:

727 27th Avenue, Villieria Pretoria 0186, South Africa

How to cite this book review: Van Alten, H.H., 2014, 'An edifying circle of pastors', Koers - Bulletin for Christian Scholarship 79(4), Art. \#2177, 2 pages. http:// dx.doi.org/10.4102/koers. v79i4.2177

\section{Read online:}

De Boer's book on the institution of the congrégations in Geneva forms part of the series Travaux d'Humanisme et Renaissance, published by Librairie Droz. At the very beginning of the introduction the author informs his readers of the aim of his book:

... to describe the so-called congrégations, the weekly meetings in which all ministers of Geneva and her neighbouring villages gathered to study the Scriptures, and the influence of this institution in the European Reformation until the beginning of the 17th century. (n.p.)

This work forms a diptych with the forthcoming Congrégationes et disputationes, in the series Opera exegetica, volume 21 . The latter will bring together in a critical edition all the documents from the study meetings of the Company of Pastors of Geneva. When one has finished reading The Genevan school of the prophets, one cannot wait to acquire and study the other half of the diptych. This statement attests to the quality of research and the breadth of its scope presented by De Boer. But let's start at the beginning.

The author divides his work into three parts.

In part 1 he explores the congrégations as seen from various perspectives. Chapter 1 is very important in that it traces the roots of this practice of weekly study meetings. Going back to 'die Prophezei' in Zurich, the author ends up discussing the central role of 1 Corinthians 14 and the meaning of prophecy as the exposition of Scripture. In this context, the gift of the languages also receives its place. The author calls the gift of the languages the 'twin sister' of prophecy. And when one realises that prophecy was understood by the reformers as the exposition of Scripture, it is not strange to see that 'the languages' were understood to be the biblical and classical languages (Hebrew, Greek and Latin). This understanding might prove to be a very helpful corrective to current charismatic views on prophecy and the gift of languages. It is also interesting to see that, when the author discusses the influence of the Genevan congrégation in the rest of Europe (part 3), 1 Corinthians 14 is again used by initiators in other parts of Europe to put this practice on a Scriptural basis.

Chapter 2 discusses the congrégation as an ecclesiastical institution, focusing on the regulations and structure surrounding this practice. Chapter 3 zooms in on the business meeting of the Company of Pastors of Geneva, a closed meeting that was conducted after the public Bible studies of Friday mornings. During this meeting, the ministers trained themselves in theology by taking turns in presenting theological propositions. Chapter 4 looks at the presence and participation of lay people during the weekly Bible studies, and it paints an interesting picture of the involvement of the elite as well as the ordinary people of Geneva. The concluding chapter of part 1 focuses on the case surrounding Jerome Bolsec, an exception in the weekly Bible studies, one which resulted in the Consensus Genevensis.

In all these chapters the author often stresses the purpose of the congrégation, namely to maintain purity and unity of doctrine. This was done, inter alia, by the public Bible studies during which the ministers took turns to expound on a portion of Scripture, by the theological propositions during the business meetings, by having candidates in theology preach and expound on Scripture, and by admonishing one another if someone said something that was not in accordance with Scripture.

Part 2 (chapters 6-8) focuses on the role of the congrégation in Calvin's project of biblical exposition. The author, however, warns his readers at the outset that this book is not primarily about Calvin, and therefore Calvin's name was omitted from the title. He rather wants to focus on the whole Company of Pastors and on the individual colleague ministers. Unfortunately, the only texts that have been preserved are almost exclusively Calvin's. As Calvin scholars we are not sad about this, but as reformed Christians who profess the community of saints, it is somewhat sad that we today cannot listen to other ministers from Geneva expounding on God's word. This

Copyright: ( 2014. The Authors. Licensee: AOSIS OpenJournals. This work is licensed under the Creative Commons Attribution License. 
predominance of texts by Calvin gives the false impression of a kind of 'omnipresence of John Calvin' (p. 13).

But despite these cautionary remarks, it is still fascinating to see how the weekly Bible studies are intricately connected to Calvin's project of biblical exposition. The author clearly shows how, specifically from 1549 onwards, the sequence of biblical books discussed at the congrégation parallels the publication of Calvin's commentaries. Calvin sometimes used the congrégation to prepare for the writing of a specific commentary, and other times the congrégation was a place where he could test his exegesis and enrich his colleagues with it.

In part 3 the author traces the legacy of the Genevan congrégation to other parts of Europe. From Geneva he travels to France and from there to the refugee churches in England and the Netherlands. It is also surprising to read that the congrégation was continued in Geneva until 1862, albeit in an altered form. The geographical spread of this practice highlights the importance that was attached to biblical exposition, preaching and doctrinal purity and unity. Sola Scriptura was thus made very concrete in these Bible study meetings that can be found across Europe during the 16th and 17 th centuries.

De Boer's The Genevan school of the prophets provides the reader with a wealth of information. The appendices only add to this. The author has the ability to grasp the attention of the reader with broad strokes as well as with intriguing detail. He often goes on speculative routes, taking the reader from Calvin's Geneva to other parts of Europe and other role-players during the Reformation before finally bringing them back to Geneva, all the whilst amassing amazing results on the way and in the end.

This, however, is also the main point of criticism. The speculative routes might yield good results, but sometimes the reader has to work through a lot of detailed information while the results are limited for the specific topic under discussion. An example can be found in paragraphs 5.9 and 5.10. Here the author wants to argue that the document which the editors of the Calvini Opera labelled as Articuli de praedestinatione was in fact Calvin's disputation in the context of the Genevan propositiones held between 1545 and 1552. After spending more than five pages arguing his position, the author concludes this could have been the case, but that it is also entirely conceivable that this manuscript page is a sketch or outline for some other oral or written exposition. There are also times when the results sound plausible, while the basis for the results might be somewhat thin.

These minor points of criticism aside, The Genevan school of the prophets is highly recommended. It is at the moment the go-to book on the Genevan congrégation. It not only discusses this specific practice, but puts it in the broad context of the Reformation of the 16th century, thereby enhancing its value beyond the limited scope of the weekly Bible study meetings. 